\title{
Relationship between ocular abnormalities and hematologic alterations in patients infected naturally by Ehrlichia canis
}

\author{
Dunia Yisela Trujillo Piso ${ }^{1^{*}}$ (i) Monica Yamile Padilla Barreto ${ }^{2}$ (1) \\ Maria del Pilar Sánchez Bonilla ${ }^{1}$ (D) Alexandre Lima de Andrade $^{3}$ (b)
}

${ }^{1}$ College of Veterinary Medicine and Animal Science, Impronta Research Group, Cooperative University of Colombia (UCC), Ibague, Tolima, Colombia. E-mail: dunia.trujillop@campusucc.edu.com ."Corresponding autor.

${ }^{2}$ Faculdade de Medicina Veterinária, Universidade Federal Rural do Rio de Janeiro (UFRRJ), Seropédica, Rio de Janeiro, Brasil.

${ }^{3}$ Departamento de Clínica Animal, Cirurgia e Reprodução, Faculdade de Medicina Veterinária, Universidade Estadual Paulista (UNESP), Araçatuba, SP, Brasil.

\begin{abstract}
To determine the association between ocular abnormalities and hematologic findings in Ehrlichia canis-infected dogs, 120 dogs suspected of canine ehrlichiosis were studied. All patients were subjected to rapid serologic diagnostic test for Ehrlichia canis, and the diagnosis was confirmed by quantitative PCR. PCR-positive patients underwent ophthalmologic examination and a hemogram and were grouped into patients with thrombocytopenia and anemia (G1), patients with thrombocytopenia (G2), and patients without hematologic disorders (G3). For ophthalmic evaluation, the patients were grouped into those having mild, severe, both mild and severe, and no ocular alterations. All patients presented with uveitis (100\%). Severe ocular disorders predominated in G1 and G2 patients. Dogs with anemia and leukopenia showed severe ocular disorders. In dogs with a greater number of leukocytes and copies/ $\mu$ l of the TRAG gene, the intraocular pressure (IOP) tends to decrease and vice versa $(r=-0.23, r=-0.26)$. In conclusion, uveitis is the earliest ocular alteration of canine ehrlichiosis. The severity of ocular abnormalities in patients with ehrlichiosis is associated with thrombocytopenia and may be aggravated by anemia and leukopenia. The hemogram and IOP are useful tools for predicting eye involvement in Ehrlichia canis-infected patients. In regions where Ehrlichia canis is endemic, the use of the tonometer should be routinely in dog general consultation.

Key words: uveitis, thrombocytopenia, Ehrlichia, IOP, hematology, TRAG gene.
\end{abstract}

\begin{abstract}
Alterações hematológicas e sua relação com anormalidades oculares em pacientes infectados naturalmente com Ehrlichia canis
\end{abstract}

RESUMO: Para determinar a associação entre anormalidades oculares e achados hematológicos em cães infectados com Ehrlichia canis, foram estudados 120 cães com suspeita de erliquiose canina. Todos os pacientes foram submetidos a um teste diagnóstico sorológico rápido para Ehrlichia canis, e o diagnóstico foi confirmado por PCR quantitativa. Os pacientes com PCR positivo foram submetidos a exame oftalmológico e hemograma completo e foram agrupados em pacientes com trombocitopenia e anemia (G1), pacientes com trombocitopenia (G2) e pacientes sem distúrbios hematológicos (G3). Para avaliação oftalmológica, os pacientes foram agrupados em pacientes com alterações leves ou graves, leves e graves e sem anormalidades oculares. Todos os pacientes apresentaram uveite (100\%). Os distúrbios oculares graves predominaram nos pacientes do G1 e G2. Cães com anemia e leucopenia apresentaram distúrbios oculares graves. Em cães com maior número de leucócitos e cópias/ $\mu l$ do gene TRAG, a pressão intra-ocular tendeu a diminuir e vice-versa $(r=-0.23, r=-0.26)$. Em conclusão, a uveite é o primeiro distúrbio ocular da erliquiose canina. A gravidade das anormalidades oculares em pacientes com erliquiose está associada à trombocitopenia e pode ser agravada por anemia e leucopenia. Hemograma e PIO são ferramentas úteis para prever o envolvimento ocular em pacientes infectados com Ehrlichia canis. Nas regiões em que o Ehrlichia canis é endêmico, o uso do tonômetro deve ser rotineiro nas consultas gerais de cães.

Palavras-chave: uveite, trombocitopenia, Ehrlichia, PIO, hematologia, gene TRAG.

\section{INTRODUCTION}

Canine ehrlichiosis is an infectious disease of great importance in the world and is reported more frequently in tropical and subtropical areas, where the presence of the vector is greater (MANNA et al., 2004). The disease is transmitted through the saliva of the tick Rhipicephalus sanguineus or blood transfusions from an infected dog to another susceptible patient (REINE, 2004). The causal agent is Ehrlichia canis, a pleomorphic rickettsia, coccoid, gram-negative, aerobic, and intracellular bacterium that multiplies in circulating mononuclear cells. Once infected, the bacteria adhere to the vascular 
endothelium, producing vasculitis and infection in the subendothelial tissue; which is responsible for the disease pattern in animals (REINE, 2004; HARRUS \& WANER, 2011).

Ehrlichiosis diagnosis should be based on a set of factors such as clinical signs, laboratory tests, medical history, and exposure to ticks. Serologic testing can be useful; however, a definitive diagnosis can only be made by morulae visualization in blood smears or by performing molecular testing to identify genetic sequences concordant with the $E$. canis genome. The most common hematologic abnormalities in infected canines include thrombocytopenia, anemia, and leukopenia. Thrombocytopenia is the most frequently reported finding in patients (BADILLO et al., 2017).

Ocular lesions are common in both natural and experimental infections of E. canis, with a prevalence that may vary between $15 \%$ and $100 \%$ of cases (KOMNENOU et al., 2007; ORIÁ et al., 2008). The commonly reported ocular diseases are anterior uveitis, panuveitis, secondary glaucoma, vitreous hemorrhage and/or retinal detachment, chorioretinitis, optic neuritis and signs related with bleeding disorders such as hyphema and conjunctival hemorrhage among others (LEIVA et al., 2005; KOMNENOU et al., 2007; VELOSO et al., 2018). Hemorrhagic eye disorder may occur in $29.4 \%$ of patients infected with $E$. canis (LEIVA et al., 2005). These disorders are a consequence of the disease, specifically by immune complex deposition in local blood vessels (HARRUS et al., 2001). This study determined the relationship between the hematologic changes and ocular abnormalities reported in patients naturally infected with $E$. canis.

\section{MATERIALS AND METHODS}

\section{Animals studied}

The study included 120 dogs with clinical profiles compatible with canine ehrlichiosis. After physical examinations, the patients were submitted to rapid test of E. canis and Anaplasma phagocitophilum/A. platys (Anigen Rapid ${ }^{\circledR}$ canis/ Anaplasma $\mathrm{Ab}$ ) based on an immunoassay for the qualitative detection of antibodies.

\section{Procedures for diagnostic confirmation}

For patients that were positive in the rapid test, two blood samples were taken. The first sample was used for confirmation of Ehrlichia spp. infection by real-time polymerase chain reaction (qPCR), which amplified the TRAG gene. This gene codes for TRAG proteins in VirD4 type IV of the secretion system of the Ehrlichia genus. The 16S rRNA gene was amplified to rule out possible false negative patients for Anaplasma spp. in the rapid test. The second sample was processed for both manual and automated blood counts. Samples with platelet agglutination, or those in which the manual platelet count was different by $15 \%$ as compared with the automated count, were excluded from the study. An ocular examination was performed on patients that were positive for Ehrlichia spp. based on the PCR analysis.

The exploration began with the evaluation of lacrimal production by the Schirmer tear test, followed by evaluation of the adnexa and ocular chambers using a slit lamp biomicroscope (Zeigen ${ }^{\circledR}$ BL III Portable). Corneal integrity was evaluated using a fluorescein dye and rose bengal. For examination of the eye fundus, the pupil was dilated with $1 \%$ tropicamide, and an indirect ophthalmoscope binocular 125 Welch Allyn was used for imaging. Ocular ultrasonography was applied when necessary and in cases of opacification of the transparent eye bulb structures. Intraocular pressure (IOP) was measured using a Perkins-type portable applanation tonometer (model Kowa ${ }^{\circledR}$ HA-2).

The study groups used for the examination were created based on the results from PCR and blood counts. In groups 1-3 (G1-G3), patients that had the following were included, respectively: anemia $(\mathrm{Ht}$ $<20 \%$ ) and thrombocytopenia (platelets $<150 \times$ $10^{9} / \mathrm{L}$ ); thrombocytopenia only; and no hematologic abnormalities. The ocular abnormalities observed were qualitatively classified as mild, severe, both mild and severe, and absent. Mild was defined as those alterations that had little impact on health and ocular physiology. Severe was defined as those alterations that severely impacted eye health and could lead to future affections (Table 1).

The analysis of variables was performed with the STATISTIX 8 program. The comparison of quantitative variables was performed by ANOVA. Chi-square significance testing was used to compare the presence or absence of eye abnormalities among the three groups. The Kruskal-Wallis test was used to compare the severity of the ocular lesions (absent, mild, or severe) among the groups. The Pearson correlation coefficient was used to see the relationship between the values of the hematocrit and the outcomes of qPCR with IOP and schirmer tear test (STT).

\section{RESULTS}

qPCR and the rapid test

$54 \%(\mathrm{n}=70)$ of patients undergoing the rapid test for detecting antibodies against E. canis 
Table 1 - Classification of eye abnormalities in Ehrlichia PCR positive dogs. The mild abnormalities are those that do not threaten vision, while severe abnormalities compromise vision or are considered serious injuries to the eye.

\begin{tabular}{lc}
\hline Mild abnormalities & Severe abnormalities \\
\hline Corneal edema & Hyphema \\
\hline Conjunctival hyperaemia & Retinal hemorrhage \\
\hline Conjunctival petechiae & Glaucoma \\
\hline Iridial petechiae & Intraocular pressure $<5 \mathrm{mmHg}$ \\
\hline Keratic precipitates & Retinal detachment \\
& Optic neuritis \\
& Retinal Perivascular edema \\
& Papilla edema \\
\hline
\end{tabular}

were positive; $15.8 \%$ presented antibodies for $E$. canis and Anaplasma spp.; 3.3\% were positive for antibodies against Anaplasma spp.; and 26.6\% were negative to the test $(n=50)$. Of the 70 positive rapid test patients, 39 were positive by PCR analysis.

The qPCR analysis of the 70 positive patients for the rapid test confirmed the diagnosis of Ehrlichia for 39 patients and 1 patient was positive for Ehrlichia sp. and Anaplasma sp. This patient was excluded from the study.

\section{Ocular alterations}

It was reported that $89.7 \%$ of dogs positive in the PCR analysis presented with ocular disorders, and $17.9 \%$ of patients had STT values less than 10 $\mathrm{mm}$. All the patients had uveitis with an average IOP of $8.3 \mathrm{mmHg}$, a value lower than the normal pressure for canines $(15-25 \mathrm{mmHg})$. Conjunctival hyperemia, was reported in $58.9 \%$ of dogs, followed by retinal perivascular edema and keratic precipitates (30.7\%).

\section{Hematology}

Of the PCR positives patients, $10.25 \%$ were anemic. Thrombocytopenia, leucopenia, and leukocytosis were present in $66.6 \%, 28.2 \%$, and $23.1 \%$ of the cases, respectively. Only $17.9 \%$ of the patients had no change in blood counts. The platelet count was on average $120.13 \times 10^{9} / \mathrm{L} \pm 87 \times 10^{9} / \mathrm{L}$. The average white blood cell count (WBC) was 11.07 $\pm 6.7 \times 10^{9} / \mathrm{L}$

\section{Hematology and study groups}

In accordance with the proposed study groups, four animals with hematocrit level less than $20 \%$ and platelet count less than $150 \times 10^{9} / \mathrm{L}$ were included in G1. Twenty-two patients with platelet counts like G1 were included in G2, and 13 patients were included in G3 (without hematologic alteration).

No significant difference in platelet counts in G1 and G2 was reported, but such a difference is present if the two groups are compared with G3 $(\mathrm{P}<0.001)$.

The leukocyte count was analyzed in the three study groups, and a statistically significant difference ( $\mathrm{P}=0.0001)$ was observed between them. The G3 had the highest count at $15.8 \times 10^{9} / \mathrm{L}$, and $38.4 \%$ of the animals had leukocytosis. In G2, the average WBC was $9.6 \times 10^{9} / \mathrm{L}, 36.4 \%$ of patients had leukopenia, and only $9 \%$ had leukocytosis. In G1, all dogs had leukopenia (average $3.4 \times 10^{9} / \mathrm{L}$ ) (Table 2).

\section{Gene copy number TRAG}

A lower number of copies/ $\mu 1$ of the TRAG gene was reported in $\mathrm{G} 3(\mathrm{P}=0.02)$ as compared with G1 and G2.

\section{Relationship of eye disorders and hematology}

In patients with thrombocytopenia and anemia (G1), the ocular abnormalities were as follows: $25 \%$ with severe abnormalities and $75 \%$ with mild and severe abnormalities at the same time (Figure 1). The most frequent alteration was retinal perivascular edema $(75 \%)$, followed by conjunctival petechiae, hemorrhage, and retinal detachment in $50 \%$ of the dogs. Iris synechiae, keratic precipitates, conjunctival hyperemia, iris bombe, hyphema, and corneal edema were less frequently found as only $25 \%$ of patients had them.

In canines with thrombocytopenia only $(\mathrm{G} 2)$, the ocular disorders reported were as follows:

Ciência Rural, v.51, n.8, 2021. 
Table 2 - General information of the study groups and average hematological values of the positive Ehrlichia dogs. The variables included in the characterization were age, gender, blood cell count: platelet count, white blood cells and hematocrit. Were also included the Gene TRAG copies by microliter.

\begin{tabular}{|c|c|c|c|c|c|c|c|c|c|c|}
\hline & \multirow[t]{2}{*}{ Group } & \multirow[t]{2}{*}{$\mathrm{N}$} & \multicolumn{2}{|c|}{--Age (years)-- } & \multicolumn{2}{|c|}{-----Gender----- } & \multirow{2}{*}{$\begin{array}{c}\begin{array}{c}\text { Platelets } \\
\left(\times 10^{\wedge} 9 / \mathrm{L}\right)\end{array} \\
\overline{\mathbf{x}}\end{array}$} & \multirow{2}{*}{$\begin{array}{c}\begin{array}{c}\mathrm{WBC} \\
\left(\times 10^{\wedge} 9 / \mathrm{L}\right)\end{array} \\
\overline{\mathbf{x}}\end{array}$} & \multirow{2}{*}{$\begin{array}{c}\text { Het } \\
(\%)\end{array}$} & \multirow{2}{*}{$\begin{array}{c}\begin{array}{c}\text { Gene TRAG } \\
\text { (Copies } / \mu 1)\end{array} \\
\overline{\mathbf{x}}\end{array}$} \\
\hline & & & $\mathrm{M}_{\mathrm{e}}$ & Rank & Male & Female & & & & \\
\hline G1 & $\begin{array}{l}\text { Anemia and } \\
\text { Thrombocytopenia }\end{array}$ & 4 & 1.75 & $0.6-3$ & 1 & 3 & 39.5 & 3.42 & 13 & 1139.8 \\
\hline G2 & Thrombocytopenia & 22 & 3 & $0.5-8$ & 11 & 11 & 77.13 & 9.66 & 35.7 & 946.18 \\
\hline G3 & $\begin{array}{l}\text { Without } \\
\text { abnormalities }\end{array}$ & 13 & 3 & $1-8$ & 9 & 4 & 217.69 & 15.81 & 43.9 & 106.31 \\
\hline
\end{tabular}

$\mathrm{M}_{\mathrm{e}}=$ Median; $\mathrm{WBC}=$ White blood cell count $\mathrm{Hct}=$ Hematocrit; $\overline{\mathbf{X}}:$ mean.

$27.3 \%$ of patients showed only mild alterations, $4.5 \%$ had severe lesions, $63.6 \%$ had both mild and severe abnormalities, and $4.5 \%$ had no ocular abnormality (Figure 1). The patients in this group presented with conjunctival hyperemia, keratic precipitates, and retinal perivascular edema at $72 \%, 36.3 \%$, and $31.8 \%$, respectively. Corneal edema was found in $18.2 \%$ of cases; congested episcleral vessels in
$13.6 \%$; corneal vascularization in $9.1 \%$; iris bombe, chemosis, tortuous retinal vessels, and glaucoma in $4.54 \%$; and retinal detachment in $13.6 \%$. The hemorrhagic lesions identified in these patients were iridales petechiae, hyphema ( $4.5 \%$ each one), and retinal hemorrhage (13.6\%).

In patients without hematologic disorders (G3), the common eye conditions were mild in 53.3\%

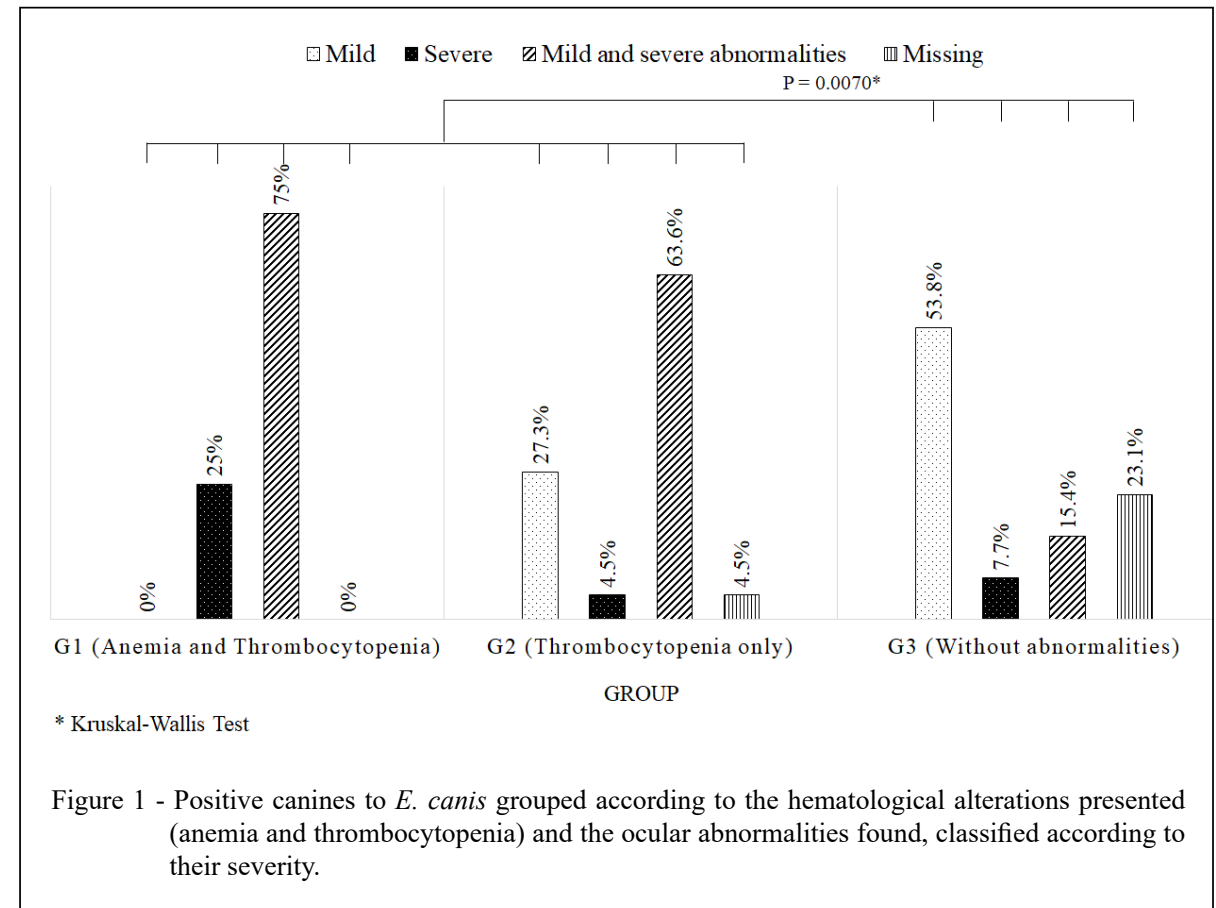

Ciência Rural, v.51, n.8, 2021. 
of dogs. Moreover, $23 \%$ of patients had no ocular abnormalities, $7.7 \%$ had severe lesions, and $15.4 \%$ had both mild and severe abnormalities. A total of $23 \%$ of patients had severe lesions. The most frequent lesions were corneal edema and conjunctival hyperemia at $38.5 \%$ and $46.1 \%$, respectively. Abnormalities such as keratic precipitates $(23.1 \%)$, retinal perivascular edema, iris bombe $(15.4 \%)$, corneal vascularization, and retinal hemorrhage and detachment were also found (7.7\%) (Figure 1).

When analyzing the impact of the ocular disorders, it was determined that there is a significant difference between the severity of disorders of at least one of the groups $(P=0.0070)$. In $\mathrm{G} 3$, patients presented with mild ocular alterations and some even presented with the absence of these, unlike G1 and G2 in which patients with severe ocular alterations predominate (Figure 1).

Patients with anemia and thrombocytopenia (G1) had more conjunctival petechiae compared to those with only thrombocytopenia $(\mathrm{G} 2)(\mathrm{P}=0.0001)$. Patients with anemia and thrombocytopenia are more likely to have posterior synechia of the iris $(\mathrm{P}=0.01)$.

\section{IOP and STT in different study groups \\ No statistically significant difference} between IOP and STT in the three groups $(\mathrm{P}=0.86$ and $\mathrm{P}=0.20$ ) was reported. The IOP average was $9.37 \pm 4.3,8.2 \pm 4.2$, and $8.15 \pm 3.97 \mathrm{mmHg}$ for $\mathrm{G} 1-$ G3, respectively. The STT average was $23 \pm 5.8,17.2$ \pm 5.6 , and $17.2 \pm 6.18 \mathrm{~mm}$ for G1-G3, respectively.

Correlation between IOP and hematologic abnormalities vs TRAG gene copy number

When evaluating the correlation between IOP and hematologic abnormalities (hematocrit and platelet counts), it was found that there is no dependence between variables $(r=0.11$ and $r=$ 0.12 ). The correlation of IOP with the WBC counts suggested that if the number of white cells is high, IOP decreases and vice versa $(r=-0.23)$ (Figure 2). No statistically significant relationship between IOP, hematocrit level, and platelet count was found.

The Pearson correlation test for the number of copies/ $\mu$ l of TRAG gene and IOP indicated that if there is a high number of copies/ $\mu$ l of TRAG gene, IOP has a tendency to decrease $(r=-0.26)$.

\section{DISCUSSION}

All 120 canines in our study showed typical clinical signs of Canine Monocytic Ehrlichiosis. Of the patients, $5,8 \%$ of positive animals presented with ocular alterations as the sole reason for seeking

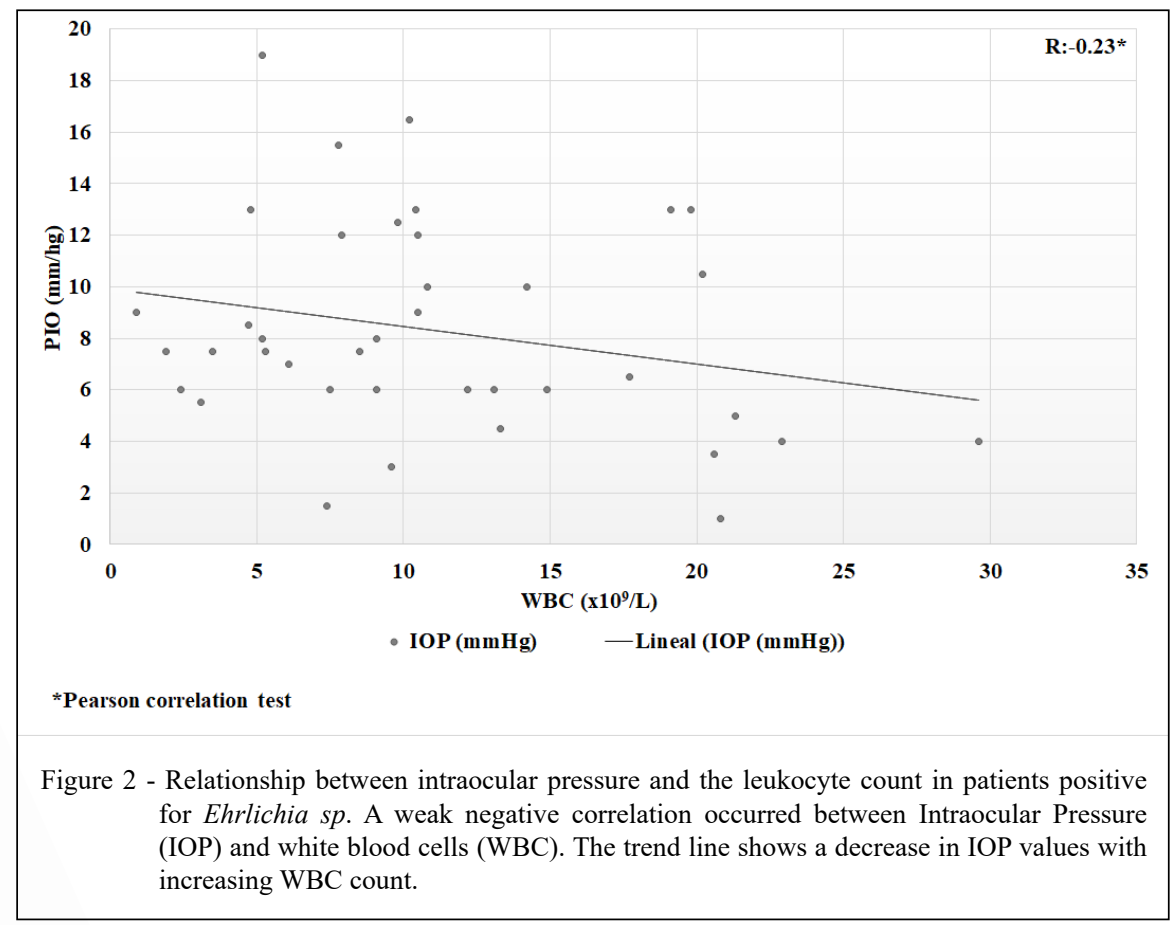

Ciência Rural, v.51, n.8, 2021. 
a consultation. Previously, studies on ophthalmic lesions due to ehrlichiosis (ORIÁ et al., 2004; LEIVA et al., 2005; KOMNENOU et al., 2007) have been reported, but few have reported on patients with ocular alterations as the sole reason for consultation (KOMNENOU et al., 2007).

$$
\text { Rapid tests based on }
$$

immunochromatographic assays to detect E. canis were applied and compared by different authors (BÉLANGER et al., 2002; DAVOUST et al., 2014), and the results reported a sensitivity ranging between $82 \%$ and $97 \%$. Wong et al. (WONG et al., 2011) carried out immunochromatographic test SNAP 4Dx and PCR tests finding SNAP 85\% concordance between the two diagnostic methods. Similarly, Carrillo et al. (CARRILLO et al., 2012) carried out rapid tests that contrasted with $\mathrm{PCR}$ to calculate sensitivity, specificity, and both positive and negative predictive values. They reported that the sensitivity and specificity are $50 \%$, the positive predictive value is $60 \%$, and the negative predictive value is $40 \%$. In the present study, the correlation between the quick serologic test and PCR was $55.7 \%$.

PCR and sequencing are more sensitive and specific diagnostic tools to detect Ehrlichia spp. Various gene sequences have been used as primers to detect the disease, but the 16S rRNA gene is the most used, as previously reported (VARGASHERNÁNDEZ et al., 2012; CAMPOS et al., 2016). The molecular diagnosis in this study was carried out based on a protein encoding gene T4SS type VirD4 genus Ehrlichia. Other T4SS proteins have been reported for E. canis diagnosis, such as VirB9 (FELEK et al., 2003). The molecular diagnosis in this study had a disadvantage because the detection performed was not specific to E. canis but applied to the entire genus. However, if one considers that the prevalence of $E$. canis in Colombia is high, it is likely that the pathogen identified by PCR is this rickettsia as well as in all PCR-positive patients' initial diagnosis made through the rapid test for $E$. canis.

Of the 70 patients positive with the bacteria in the rapid test, only 39 were positive for infection with molecular testing. This might mean that the patient was in contact with rickettsia, and the immune system or previous treatment managed to eliminate it. Once the pathogen is eliminated, the antibody titers can be maintained at high levels for months (REINE, 2004).

Hemogram alterations in patients with canine ehrlichiosis mainly include thrombocytopenia, anemia, and leukopenia. In the present study, 10.2\% of patients had anemia, $66.6 \%$ had thrombocytopenia,
$28.2 \%$ had leucopenia, and $23.1 \%$ had leukocytosis. These results do not differ from what has already been reported in the literature. In his research in Colombia, CARRILLO et al. (2012) showed that $10 \%$ of patients with suggestive symptoms of $E$. canis infection had anemia. With respect to thrombocytopenia, it was reported in $73 \%-64 \%$ of patients (ÖZATA \& URAL, 2014), similar to our results. Other accounts differ from those found here. For example, CARRILLO et al. (2012) and BADILLO et al. (2017) reported a percentage of patients with Ehrlichia that presented thrombocytopenia this finding as $80 \%$ and $48 \%$, respectively. An explanation for these differences might be that the platelet count, varies according to the stage of the disease. In the acute phase, thrombocytopenia can be moderate to severe; in the subclinical phase, thrombocytopenia can be mild; and in the chronic phase, hematologic findings suggested severe thrombocytopenia (HARRUS \& WANER, 2011). Most of the patients under study presented with leucopenia. This suggested that patients were mostly in the acute or subclinical disease states (HARRUS \& WANER, 2011) when contrasted with the results of the hematocrit level and platelet count.

The $89.7 \%$ of positive patients with active Ehrlichia spp. infections in our study had ocular disorders, in contrast with previously published results (MARTIN, 1999; LEIVA et al., 2005; KOMNENOU et al., 2007), in which the percentage of dogs with this condition was lower. These studies used different diagnostic techniques based on antibody titers than what we used. The issue with their method is that it did not detect the agent, which does not ensure that patients were infected at the time of the study (LIN, 2015). Such a difference may be related to the stage of the disease the animals were studied at, because the acute phase presents a greater number of ocular signs (MARTIN, 1999). When the techniques used are like those used here, the results are more similar. For example, Oriá et al. (ORIÁ et al., 2008) reported a percentage of presentation of ocular disorders at $86.3 \%$ in a study of 44 patients diagnosed with ehrlichiosis through the dot-blot technique and the IFATT-linked immunoassay. Their results and ours are similar and coincide because the identification of the causative agent was conducted through at least two different laboratory techniques.

Uveitis is an important manifestation of the ehrlichiosis eye due to vasculitis, deposition of immunocomplexes, and bleeding of one or more ocular structures. All patients involved in this study demonstrated a decrease in IOP, which is a common finding in uveitis because inflammation of the anterior 
uvea leads to a reduction of the active secretion of the aqueous humor (COOK et al., 2008).

Thegroupofpatientswiththrombocytopenia and anemia presented with predominantly severe ocular disorders, where retinal perivascular edema acquired great importance because it was the most common. Perivascular edema, reported mainly in the lungs and other organs, occurs as a consequence of anemia and interstitial bleeding. In turn, this causes systemic hypotension and ischemia-reperfusion (ENGLER et al., 1982). Systemic hypotension may be considered an incidental finding in humans with E. chaffeensis and dogs with E. canis, especially in those where the hematocrit level is less than $15 \%$ (PEDA et al., 2014). This hypotension in canine patients has high association with cardiac disorders, because the $E$. canis agent triggers cardiomyopathies (KITTLESON, 1998). This is derived from initial severe anemia observed in the clinical diagnosis and is associated with an increased probability of heart damage (DINIZ et al., 2008). This pathophysiology can lead to ischemia-reperfusion, which can cause several organs to be compromised by the generated mediators. Additionally, this can cause remote injury or damage to distant organs such as the retina, where damage arising from systemic diseases derived from arteriosclerosis in humans has been reported (YOKOTA et al., 2011). Furthermore, in some cases this has resulted in the eye primary form as a result of glaucoma, central retinal occlusion artery occlusion, or ophthalmic artery (OSBORNE et al., 2004). To our knowledge, there are no studies on the reperfusionischemia syndrome that has been associated with $E$. canis as the initial cause and subsequent remote injury in an organ such as the eye. However, these results may constitute a baseline for future studies, where cardiomyopathies of patients infected with rickettsia, ischemia-reperfusion syndrome, and retinal function should be considered.

Hemorrhagic ocular disorders, such as conjunctival petechiae, retinal hemorrhages, and retinal detachment, are frequently observed in animals with anemia and thrombocytopenia (KOMNENOU et al., 2007; ORIÁ et al., 2008). There are notable differences between the results of this study compared to KOMNENOU et al. (2007) and ORIÁ et al. (2008), specifically referring to the frequency of occurrence of hemorrhagic signs, because the values obtained in this study are higher than those referenced. Thrombocytopenia or platelet dysfunction is often the cause of these hemorrhagic ocular disorders. Similarly, antibodies, antiplatelets, and secondary blood hyperviscosity to monoclonal gammopathy have been reported. Oncotic pressure increase and vasculitis are also factors included in the pathogenesis of ocular bleeding (HARRUS et al., 1998).

PCR positive patients without hematologic disorders also presented with uveitis and mild alterations, or showed no ocular abnormalities. This finding demonstrated the influence of a competent immune system in an organ such as the eye, because it can be inferred that uveitis is the most important initial ocular manifestation of systemic diseases such as ehrlichiosis, at least in regions where the disease is considered to be endemic. Other studies also report on uveitis as the most common disorder in dogs with ehrlichiosis (LEIVA et al., 2005). IOP is related to leukocyte count and the number of copies/ $\mu 1$ of the TRAG gene, because IOP tends to decrease as the count and number of copies increase.

\section{CONCLUSION}

In conclusion, patients with ehrlichiosis that present with thrombocytopenia, anemia, and leukopenia are likely to develop severe ocular disorders that can be prevented prematurely by analysis of the hematocrit level and a detailed eye examination. The use of the tonometer in canine patients inhabiting endemic regions of Ehrlichia canis should be as routine for clinical examination, as the use of the stethoscope.

\section{ACKNOWLEDGEMENTS}

The authors wish to thank the staff of the Veterinary Hospital of the Veterinary Medicine and Animal Science School of the Colombian Cooperative University, Ibagué- Colombia, for his collaboration with the patients under study and the Comité Nacional para el Desarrollo de la Investigación de la Universidad Cooperativa de Colombia (CONADI) for financial support (INV1808).

\section{BIOETHICS AND BIOSSECURITY COMMITTEE APPROVAL}

This study adhered to the ARVO Statement for Use of Animals in Ophthalmic Vision and Research. All procedures involving dogs followed the Ethical Principles of Animal Experimentation established by the Ethics Committee on Animal Use (protocol number 146) of the La Salle University-Colombia.

\section{DECLARATION OF CONFLICT OF INTEREST}

The authors declare no conflict of interest. The founding sponsors had no role in the design of the study; in the collection, analyses, or interpretation of data; in the writing of the manuscript, and in the decision to publish the results. 


\section{AUTHORS' CONTRIBUTIONS}

All authors contributed equally for the conception and writing of the manuscript. All authors critically revised the manuscript and approved of the final version.

\section{REFERENCES}

BADILLO, M. et al. Infection by Ehrlichia canis and Anaplasma $\mathrm{sp}$. in dogs attended in veterinary clinics , Barranquilla, Colombia. Revista MVZ Córdoba, v.22, p.6023-6033, 2017.

BÉLANGER, M. et al. Comparison of serological detection methods for diagnosis of Ehrlichia canisiinfections in Dogs Comparison of Serological Detection Methods for Diagnosis of Ehrlichia canis Infections in Dogs. Journal of Clinical Microbiology, v.40, n.9, p.3506-3508, 2002. Available from: $<$ https://doi.org/10.1128/JCM.40.9.3506>. Accessed: Jul. 09, 2020. doi: $10.1128 / \mathrm{JCM} 40.9 .3506$.

CAMPOS, L. et al. Molecular detection and identification of Rickettsiales pathogens in dog ticks from Costa Rica. Ticks and Tick-borne Diseases, v.7, n.6, p.1198-1202, 2016. Available from: <https://doi.org/10.1016/j.ttbdis.2016.07.015>. Accessed: Jul 09, 2020. doi: 10.1016/j.ttbdis.2016.07.015.

CARRILLO, L. M. et al. Implementation of a PCR-based method for the diagnosis of Ehrlichia spp, in canine in Medellin (Colombia )*. Revista CES, v.7, n.2, p.38-46, 2012.

COOK, C. S. et al. Clinical basic science. In: PETERSENJONES, R. P. S. (Ed.). . Small Animal Ophthalmology. 4th. ed. Philadelphia: Saunders Ltd., 2008. p. 1-13.

DAVOUST, B. et al. Usefulness of a rapid immuno-migration test for the detection of canine monocytic ehrlichiosis in Africa. Comparative Immunology, Microbiology and Infectious Diseases, v.37, n.1, p.31-37, 2014. Available from: <https://doi. org/10.1016/j.cimid.2013.10.005>. Accessed: Jul 09, 2020. doi: 10.1016/j.cimid.2013.10.005.

DINIZ, P. P. V. P. et al. Serum c para manter uniformidade todas as primeiras letras minúsculaardiac Troponin I Concentration in Dogs with Ehrlichiosis. Journal of Veterinary Internal Medicine, v.22, n.5, p.1136-1143, 2008. Available from: <https://doi.org/1 0.1111/j.1939-1676.2008.0145.x>. Accessed: Jul. 09, 2020. doi: 10.1111/j.1939-1676.2008.0145.x.

ENGLER, R. L. et al. Leukocyte capillary Plugging in Myocardial Ischemia and Reperfusion in the Dog. American Journal of Pathology, v.111, n.1, p.98-111, 1982.

FELEK, S. et al. Sequence and expression Analysis of virB9 of the Type IV Secretion System of Ehrlichia canis Strains in Ticks , Dogs , and Cultured Cells. Infection and Immunity, v71, n.10, p.6063-6067, 2003. doi: 10.1128/IAI.71.10.6063-6067.2003.

HARRUS, S. et al. Acute blindness associated with monoclonal gammopathy induced by Ehrlichia canis infection. Veterinary parasitology, v.78, n.2, p.155-60, 1998. Available from: <https:// doi.org/10.1016/s0304-4017(98)00132-0>. Accessed: Jul 09, 2020. doi: 10.1016/s0304-4017(98)00132-0.

HARRUS, S. et al. Presence of immune-complexes, and absence of antinuclear antibodies, in sera of dogs naturally and experimentally infected with Ehrlichia canis. Veterinary microbiology, v.83, n.4, p.343-9, 2001. Available from: <https://doi.org/10.1016/S03781135(01)00431-X>. Accessed: Jul. 09, 2020. doi: 10.1016/S03781135(01)00431-X.

HARRUS, S.; WANER, T. Diagnosis of canine monocytotropic ehrlichiosis (Ehrlichia canis): An overview. The Veterinary Journal, p.292-296, 2011. Available from: <https://doi. org/10.1016/j.tvj1.2010.02.001>. Accessed: Jul. 09, 2020. doi: 10.1016/j.tvj1.2010.02.001.

KITTLESON, M. Primary myocardial disease leading to chronic myocardial failure (dilated cardiomyopathy and related diseases). In: Small Animal Cardiovascular Medicine. 1. ed. Philadelphia: Mosby, 1998. p. 319-346.

KOMNENOU, A. et al. Ocular manifestations of natural canine monocytic ehrlichiosis (Ehrlichia canis): A retrospective study of 90 cases. Veterinary Ophthalmology, v.10, n.3, p.137-142, 2007. Available from: <https://doi.org/10.1111 /j.1463-5224.2007.00508.x>. Accessed: Jul. 09, 2020. doi: 10.1111/j.1463-5224.2007.00508.x.

LEIVA, M. et al. Ocular signs of canine monocytic ehrlichiosis: A retrospective study in dogs from Barcelona, Spain. Veterinary Ophthalmology, v.8, n.6, p.387-393, 2005. Available from: $<$ https://doi.org/10.1111/j.1463-5224.2005.00409.x>. Accessed: Jul. 09, 2020. doi: 10.1111/j.1463-5224.2005.00409.x.

LIN, A. V. Indirect ELISA. In: HNASKO, R. (Ed.). . ELISA Methods and Protocols. [s.1.] Springer, 2015. p. 51-61.

MANNA, L. et al. First molecular characterization of a granulocytic Ehrlichia strain isolated from a dog in South Italy. Veterinary journal (London, England: 1997), v.167, n.3, p.224-7, 2004. Available from: <https://doi.org/10.1016/j.tvj1.2004.02.008>. Accessed: Jul. 09, 2020. doi: 10.1016/j.tvj1.2004.02.008.

MARTIN, C. Ocular manifestations of systemic disease. Veterinary Ophthalmology, p. 1401-1447, 1999.

ORIÁ, A. et al. Ophthalmic, hematologic and serologic findings in dogs with suspected Ehrlichia canis infections. R. Bras. Ci. Vet, p.94-97, 2008. Available from: <http://dx.doi.org/10.4322/ rbcv.2014.202>. Accessed: Jul 09, 2020. doi: 10.4322/rbcv.2014.202.

ORIÁ, A. P. et al. Uveitis in dogs infected with Ehrlichia canis. Ciência Rural, v.34, n.4, p.1289-1295, 2004. Available from: $<$ https://doi.org/10.1590/S0103-84782004000400055>. Accessed: Jul. 09, 2020. doi: 10.1590/S0103-84782004000400055.

OSBORNE, N. N. et al. Retinal ischemia : mechanisms of damage and potential therapeutic strategies. Progress in Retinal and Eye Research, v.23, n.1, p.91-147, 2004. Available from: <https://doi. org/10.1016/j.preteyeres.2003.12.001>. Accessed: Jul. 09, 2020. doi: $10.1016 /$ j.preteyeres.2003.12.001.

ÖZATA, F.; URAL, K. Thrombocyte indices in dogs infected with Ehrlichia canis and Anaplasma phagocytophilum. MVZ Córdoba, v.19, n.3, p.4277-4288, 2014.

PEDA, A. et al. Dermatophytosis in a Dog Seropositive for Ehrlichia Spp. Journal of Veterinary Science \& Animal Husbandry, v.2, n.2, p.21-23, 2014. Available from: $<$ https://doi. org/10.15744/2348-9790.1.501>. Accessed: Jul. 09, 2020. doi: $10.15744 / 2348-9790.1 .501$. 
REINE, N. J. Infection and blood transfusion: Aguide to donor screening. Clinical Techniques in Small Animal Practice, v.19, n.2, p.68-74 2004. Available from: <https://doi.org/10.1053/j.ctsap.2004.01.002>. Accessed: Jul. 09, 2020. doi: 10.1053/j.ctsap.2004.01.002.

VARGAS-HERNÁNDEZ, G. et al. Molecular and serological detection of Ehrlichia canis and Babesia vogeli in dogs in Colombia. Veterinary Parasitology, v.186, n.3-4, p.254-260, 2012. Available from: <https://doi.org/10.1016/j.vetpar.2011.11.011>. Accessed: Jul. 09, 2020. doi: 10.1016/j.vetpar.2011.11.011.

VELOSO, J. F. et al. Molecular diagnosis of Ehrlichia canis infection in dogs with uveitis Diagnóstico molecular da infecção por Ehrlichia canis em cães com uveíte. Ciências Agrárias, v.39, n.3, p.1049-1056, 2018. Available from: <https://doi. org/10.5433/1679-0359.2018v39n3p1049>. Accessed: Jul. 09, 2020. doi: 10.5433/1679-0359.2018v39n3p1049.

WONG, S. S. Y. et al. Comparative Evaluation of a Point-ofCare Immunochromatographic Test SNAP 4Dx with Molecular Detection Tests for Vector-Borne Canine Pathogens in Hong Kong. Vector-Borne and Zoonotic Diseases, v.11, n.9, p.1269-1277, 2011. Available from: <https://doi.org/10.1089/vbz.2010.0265>. Accessed: Jul. 09, 2020. doi: 10.1089/vbz.2010.0265.

YOKOTA, H. et al. Neuroprotection from retinal ischemia / Reperfusion Injury by NOX2 NADPH Oxidase Deletion. Investigative Ophthalmology \& Visual Science, v.52, n.11, p.8123-8131, 2011. Available from: <https://doi.org/10.1167/ iovs.11-8318>. Accessed: Jul. 09, 2020. doi: 10.1167/iovs.11-8318. 